\title{
Local Configurations of Violence: Warlords, Tribal Leaders and Insurgents in Afghanistan
}

\author{
Conrad Schetter and Rainer Glassner*
}

\begin{abstract}
On the backdrop of a weak central government the article examines three types of local configurations of violence in Afghanistan. The concentration of power at the local level is so strong, that even the core institutions of the state are under control of local interests. Thus, in Kandahar province powerful tribal individuals control the means of violence. The combination of insurgency, drug networks and tribal structures has encouraged the emergence of strong warlords and the Taliban in Kandahar. In contrast to Kandahar, Kunduz province shows myriads of mini-fiefdoms as well as localized 'rules of law', or 'rules of the gun', which result in fragmented warlordism. Finally, in Paktia province tribal identities are the most important points of reference. The Pashtun tribal code of law and behavior is the 'rule of the game', and Paktia tribes settle their conflicts in tribal gatherings by discussion until a consensus is reached.
\end{abstract}

Keywords: Afghanistan, insurgents, tribes, warlords

Afghanistan, Aufständische, Stämme, Warlords

\section{Introduction}

$\mathrm{P}$ olicy-makers, journalists and researchers time and again stress the lack of physical security in Afghanistan by circumscribing it with the term 'warlordism' (see Giustozzi 2009a). Since the intervention in 2002, virtually no influential Afghan political figure has escaped this label, which has subsequently became the category to describe all actors trying to spoil, or even cast doubts, on the international agenda of the Afghan reconstruction process. The term jang salar (Dari term for 'warlord'), which had never been used in the Afghan parlance in the past, found its way into the Afghan rhetoric and is used - in contrast to the commonly used term comandan in a very negative sense. However, the manifold forms of individual leadership as well as local differences regarding the control of the means of violence are significant and have to be kept in mind while using the overarching term 'warlord'. This article examines local configurations of violence using three case studies - Kunduz, Kandahar and Paktia - to elaborate on forms of local leadership in Afghanistan.

\section{Role of the Central State}

The Afghan state never developed beyond an embryonic status in the past. The protracted war since 1979 destroyed the remaining state structures completely. The government, which was established in December 2001, possessed neither a well-founded nor an overall accepted authority. Hence the primary objective of the Afghan government was to re-establish a state-owned monopoly of violence by dismantling local militias or integrating them into formal security structures with the assistance of the international community. However, the Disarmament, Demobilization and Reintegration process (DDR) from 2003 to 2005, and the subsequent Disbandment

Conrad Schetter, Dr. PD., is Senior Reseacher at the Center for Developmen Research (ZEF), University of Bonn; Rainer Glassner, GIZ Office, Islamabad, Pakistan. of Illegal Armed Groups (DIAG) from 2005 to 2011, failed to disband the 'clientelistic' structures of commanders and their militiamen (Giustozzi 2008). In most cases, influential commanders were able to preserve their power by assuming formal positions in the government or by transforming their militias into regular army or police units. As a result, the security sector of the state is made up, to a large extent, of warlords and their militias (Schetter 2005).

While Afghan president, Hamid Karzai followed a strategy of co-opting warlords, at the same time he aimed to restrict their power by rotating governors, ministers and police chiefs from one position to another in order to prevent them from consolidating their local power bases. This policy showed limited success during the first years of the Karzai administration. However, since 2005 this policy has failed time and again. Local elites in several provinces mobilized their clients and demonstrated that the appointment of a new provincial authority would lead directly to destabilization of the province. A symptomatic example was Juma Khan Hamdard, who was appointed by Hamid Karzai as the governor, first of Jawzjan province, and then of Kunduz province. Hamdard, who is an ethnic Pashtun and was a former member of Hikmatyar's Hizb-i Islami, was at various times allied to or fighting against many of today's 'warlords' in Northern Afghanistan during the 1990s. In May 2007, Rashid Dostum, one of the dominant warlords in Northern Afghanistan, organized a demonstration against Governor Hamdard in Sheberghan, the provincial capital of Jawzjan. Hamdard was accused of incompetence and ethnic prejudice. The demonstration turned violent. To prevent a destabilization of the situation in Jawzjan, Hamid Karzai decided to withdraw Hamdard from Jawzjan and appoint him as governor to Kunduz. When rumors about this decision became public at the end of 2007 , protests immediately began there as well. Local elites, related to the local warlord Mir Alam, who fought against Hamdard in the 1990s, organized protests. Again, Karzai gave in to the pressure and withdrew the appointment.

In contrast to the limited room of maneuver of the Afghan government in the provinces, local elites strongly influence the 
political center in Kabul. Often local elites are associated with political decision-makers in Kabul by family ties. For example, the Afghan Interior Ministry wanted to replace Abdul Ali, the chief of police in Farkhar district in Takhar province. However, Abdul Ali managed to defend his position by using his family ties to high-ranking officials in the Kabul government, who directly intervened to reverse the decision in the responsible office.

The weakness of the central government highlights the importance of studying local configurations of violence.

\section{Kandahar - Feudal Warlordism}

The city of Kandahar is not only the capital of the province of the same name, but also the main city in Southern Afghanistan. Kandahar served as a stronghold and de facto capital during the rule of the Taliban (1994-2001). Large parts of the population of Kandahar are members of Pashtun tribes, which are structured in a hierarchical manner. The tribal system in Kandahar is shaped by common tribal identities combined with strong hierarchies. During the 18th century a tiny landowning aristocracy had emerged within each tribe, which managed to seize the economic resources and control local decision-making processes, while ordinary tribesmen often ended up as their clients (hamsayagan).

Tribal hierarchies are reflected in control of the means of violence of today's Kandahar province. Within each large tribe we find either a single person or a small number of powerful individuals stemming from landlord or business families and maintaining their own private militias. The powerful elite of Kandahar province consists of no more than half a dozen men. Members of this elite compete for the control of core government positions to extend their regional influence.

The central figures - Ahmad Wali Karzai and Gul Agha Shirzai are representatives of these structures of violence. Ahmad Wali Karzai, who was assassinated on 12 July 2011, was the younger brother of President Hamid Karzai and the head of the provincial council of Kandahar province. The Karzai family has been influential in the Kandahar region for decades and is one of the leading families of the Popalzai tribe, to which the king's family belongs. Ahmad Wali Karzai made use of his closeness to Hamid Karzai while at the same time being the main leader of the Popalzai tribe in Southern Afghanistan to acquire power. He was also said to control a large share of the drug trade in the region (Baldauf 2004; Gall 2004). His assassination has left a power vacuum behind and dramatically weakened the position of Hamid Karzai in Kandahar.

The Barakzai are the second largest tribe in Kandahar province after the Popalzai. The most prominent tribal leader is Gul Agha Shirzai. In contrast to Ahmad Wali Karzai, Gul Agha Shirzai is not a descendant of the tribal aristocracy. His father, Haji Latif, was an important mujahidin commander in the 1980s and his family gained influence due to large property holdings. Gul Agha Shirzai served twice as provincial governor of Kandahar and for a short period as a minister in Hamid Karzai's cabinet. He must be considered one of the most powerful men in
Kandahar, not least since he integrated his militias into the Afghan National Police during the DDR process. His militias have also assisted the Coalition Forces in fighting insurgents. Notwithstanding Hamid Karzai's attempt to weaken Shirzai's position by appointing him governor of Nangrahar, Shirzai still has a decisive influence on local politics in Kandahar.

Since 2001 the situation in Kandahar is strongly influenced by the US-driven 'War on Terror' and the counter-insurgency. While valid information about the latter is rare (Giustozzi 2007; 2009b), it is interesting to note that the insurgents are deeply embedded in local communities. The rural areas, where the Taliban began their rapid military expansion in the mid-1990s, have become the backbones of the movement. The local population perceives the physical security provided by the Taliban to be more effective than the one offered by the government, which is seen as corrupt (Giustozzi 2007). The Taliban display ambiguity about the tribal structures: on the one hand they stick to tribal codes and values, on the other they challenge the hierarchical system of the Southern tribes by demanding social justice. Thus, the Taliban present themselves as advocates of the marginalized people on the bottom end of the tribal pyramid. The military operations of the Coalition Forces, such as routine house searches, have strengthened the relationship between the Taliban and the local population. Due to the high intensity of fighting between the Taliban and the Coalition Forces, the local elites were forced to position themselves either with the Coalition Forces or with the Taliban.

Finally, opium cultivation has a strong impact on the security situation. Since 2001, 10 to 15 percent of the Afghan area under poppy cultivation is situated in Kandahar province. The dominance of the opium economy is so strong that hardly any elite family can maintain a leading position - in the tribes or in the government - without an involvement in the drug economy. Thus, the drug trafficking networks make use of both government and Taliban, depending on which group controls a particular area.

Summing up, during the last few years, the combination of insurgency, well-financed drug networks and hierarchical tribal structures has restricted the influence of the Afghan government in Kandahar province and, instead, has encouraged the emergence of strong warlords as well as the strengthening of the the Taliban. Government control only takes place via tribal or personal affiliations.

\section{Kunduz - Fragmented Warlordism}

Despite the long distance between the capital Kabul and Kunduz, as well as the geographical barrier of the Hindu Kush mountain range, the Afghan state has been influential in the northeastern province of Kunduz since its emergence as a state at the end of the 19th century (Noelle 1997). The government initiated colonization by Pashtuns from the South, which took place in several waves since the early 1920s. The newcomers received large landholdings, mainly confiscated from Uzbek landlords by an administrative apparatus controlled by 
Pashtuns. This colonization triggered severe tensions between the local population and the Pashtun immigrants.

This historical anchorage of the Afghan state in Kunduz has a significant influence on the constellation of today's power structures. Holding an official position in Kunduz province is regarded by the elites as a guarantee of power and as an important material as well as symbolic resource. High-ranking officials within the highway, border and provincial police are deploying policemen for their own interest.

Due to the ethnic diversity of the province and the frequently changing front lines during the war, there are, in contrast to the situation in Kandahar, no universally accepted communal forms of organization and institutions that are capable of checking and balancing the power of individuals. This has resulted in myriads of mini-fiefdoms as well as localized 'rules of law' or 'rules of the gun'. Each village is headed by a 'chieftain', often an individual who held a position as commander during the 1980s and 1990s civil wars. Opinions about these local elites differ from place to place: while some are seen as honorable, others are described as killers and thieves. Alliances among militias tend to be brokered on a broader scale and seldom rely exclusively on tribal, ethnic or regional similarities. The configurations of violence throughout the province vary from place to place as the subsequent descriptions show.

The Imam Sahib district is situated on the border with Tajikistan. It is an agrarian, fertile district and a key hub for the drug-trade. Both the district and the office of the chief of the border police are strategically very significant. Imam Sahib is dominated by the Ibrahimis, an Uzbek clan, which rose from obscurity to become the predominant family of that district and beyond, in the course of the war. Ibrahim Abdul Latif of the Ibrahimi clan became the governor of Kunduz province in 2002, before being appointed governor of Faryab in 2004. His brother Haji Raoof earned a reputation as comandan, headed the border police in Imam Sahib and won a seat in the parliamentary elections. Finally, the locally strategically important position of mirab bashi (water bailiff or water commissioner), who controls the farmers' access to the key resource of water, is in the hands of Afiz, Haji Raoof's brother in law. Thus, the Ibrahimis control access to public resources.

The district of Khanabad provides a different picture. During the war, the district was under the control of Comandan Amir. After his death, he was succeeded by his brother Ghulam, who lost several of his sub-commanders in the upsurge of ethnic and political division after the collapse of the Taliban. This led to the emergence of myriads of loosely connected small warlords, rarely controlling more than one village. Their actions are solely restricted by the competition with other commanders.

Most of the conflicts in Kunduz in recent years have revolved around land disputes between returnees who went to exile in Pakistan during the war, and those who remained in Kunduz. These conflicts are complicated by the fact that, depending on the political front lines of war, land ownership often changed hands from one owner to another during wartime. Additionally, conflict over land tenure often coincides with the ethnic composition of the province. Most of the returnees are Pashtuns, who claim their lands back and feel sidelined by the administrative structures, which are today dominated by non-Pashtun elites who were able to establish and enlarge their power bases during the war. These land conflicts are strongly interwoven with the recent emergence of the Taliban. Indeed the Bundeswehr, which is running the Provincial Reconstruction Team (PRT) in Kunduz, is talking about "Pashtun pockets", which harbor and support Taliban fighters. The Bundeswehr analysis is based on the fact that most ambushes and roadside explosion occur along the roads to Pashtun settlements in the districts of Chardara, Aliabad and Khanabad (Giustozzi and Reuter 2011).

Summing up, numerous warlords, who differ widely in the scope of their influence and power, are controlling the means of violence in Kunduz province. Moreover, varying configurations of violence from district to district and sometimes, as in Khanabad, from village to village, can be observed. Finally the siding with or against the insurgents can be traced back to historical coagulated socioeconomic tensions.

\section{Paktia - Rule of the Tribes}

Paktia province is located in the eastern part of the so-called Pashtun belt. Despite its geographical proximity to the capital Kabul, state influence in Paktia has always remained weak, which is largely the result of the strength of the Pashtun tribal system. By the end of the 1970s, state influence did not extend beyond the provincial capital of Gardez. During the lifetime of the Taliban government, the Taliban were only present in the provincial capital. Even today the power of the government is very limited: The Afghan National Army and the Afghan National Police are concentrated in Gardez and along the overland roads, but absent in the hinterlands.

The Pashtuns of Paktia are divided along tribal lines. Tribal identities are still perceived as the most important points of reference, incorporating ideas of honor and justice as well as daily behavior (Glatzer 2002). The pashtunwali, the Pashtun tribal code of law and behavior, is the commonly accepted 'rule of the game', which is binding for everybody and provides strict guidelines on how to deal with any specific situation. In contrast to Kandahar, the tribal system in Paktia is much more egalitarian. Thus, the underlying notion of pashtunwali is that all tribesmen have an equal status and no one should possess more rights and power than any other (Janata and Hassas 1975). According to this notion, the Paktia tribes settle their conflicts in tribal gatherings (jirga) by discussion until a consensus is reached.

Due to this equal status of the tribesmen, political leadership is always hard to win. This is why the last two decades have been characterized by a continuous struggle between the tribes and individual strong men - first the mujahidin, then the warlords. As soon as the latter behaved contrary to the codes of the pashtunwali, conflicts arose between them and the tribes. This was the case after the collapse of the Taliban in the winter of 2001/2, when Bacha Khan, an anti-Taliban warlord of the Zadran tribe, seized power as governor of the Paktia province. He was able to mobilize warriors from his Zadran tribe as well 
as some commanders from other tribes. Due to the arbitrary way in which he gained power over the province, most of the tribes regarded him as an illegitimate 'bandit', who did not obey the pashtunwali. Within a few days, the tribes reacted to Bacha Khan's seizure of power and managed to oust Bacha Khan from Gardez.

Since that incident, policing in the tribal areas of Paktia has been carried out by the arbakee, a traditional tribal police engaged in community policing (Schmeidl and Karokhail 2009). According to the tribal system, the arbakee implement the decisions of a jirga and are controlled by tribal elders. Initially, the arbakee represented a spontaneous force, which was only acting as long as the tribal jirga needed it. But since 2002 the state has been permanently financing the arbakee and officially handed over several security tasks such as road security to the arbakee. The arbakee fulfill classical police tasks as well as the protection of tribal resources such as forests and pastures; they became an institutionalized force. The arbakee enjoy a much broader acceptance by the local population than the regular police, who are - as in Kandahar and Kunduz regarded as corrupt and ineffective.

The tasks of the arbakee are highly dependent upon the tribal norms and values (e.g. blood feud), which in many cases are opposed to Western ideas, but in full accordance with the pashtunwali. The arbakee do not constitute neutral forces, but are time and again involved in tribal rivalries. One example is the long-lasting tribal feud between the Ahmadzai tribe and the neighboring Totakhel tribe, which was aggravated by the establishing of the arbakee.

In Paktia most of the tribes aim to stand apart from the conflict between the insurgents and the government and international troops. The tribes had successfully followed the same strategy during the Soviet occupation, whereby they allowed the insurgents and the government (as well as the international actors) to cross their tribal territories as long as no one challenged the tribal order. The attempts by NATO and the Afghan government to direct the arbakee against the insurgents have shown little success. In general, most tribal leaders just observe this ideological conflict and maintain their networks with influential actors on all sides. Tribal leaders have to follow the egalitarian principals in both their rhetoric and behavior. In other words, the tribal system in Paktia obstructs or at least constrains the emergence of warlordism as well as the influence of the state. By contrast, in the southern district of Zurmat, where the tribal system with its myriads of tribes and clans is rather fragmented and tribal codes are weakened, the insurgents have gained more support than in those parts of the province, where tribal structures are more stable (Trives 2006).

\section{Configurations of Violence}

After the fall of the Taliban people "hated the commanders, but now they love them again", one informant told us in Kunduz. This statement reflects the strong reservations about the return of the Taliban among many Afghans, especially in the North, as well as the inability of the international actors to establish a new political order. It shows that many Afghans, due to the absence of a reliable state, regard the 'warlordism' as at least better than an unpredictable future.

As the case of Kunduz demonstrates, one can even find a variety of constellations within a single province, often diverging from valley to valley and from village to village. The basic observable dimensions affecting the local configurations of violence are the social organization and the economic resources as well as the presence of the state and international organizations.

Social structures play an important role and have to be examined in the local context. The different social structures in Paktia and Kandahar make clear that their characterization as 'tribal Pashtuns' is too superficial and does not say anything meaningful about the tribal impact on the configurations of actors of violence. The history of a region has to be taken into consideration: Due to the colonization process of the 20th century the population of Kunduz is shaped by a heterogeneity on the one side, and by a rift between the Pashtun latecomers and the earlier inhabitants on the other. The absence of common values and rules has contributed to the fragmentation of warlordism in Kunduz. Paktia provides the opposite example. The egalitarian tribal culture, which is accepted by the people at large, has averted warlordism.

Local economies impact the configurations of actors of violence. In regions such as Kandahar, which rely heavily on drug cultivation and drug trade, one can witness the establishment of strong warlord structures. Apparently, the financial resources deriving from the drug economy contribute to the strengthening of the hierarchical structures. This argument is supported by the example of Kunduz, where a strong clan succeeded in establishing itself in the district of Imam Sahib, which is strategically important for drug smuggling, while the district of Khanabad, which has not benefited from the cultivation of drugs, faces a fragmentation of the control over power and violence.

In general, the state aims to control the security sector and to establish a monopoly of violence. One could imagine that in places where the state is more accepted, the dominance of the warlords would be easier to break. But, contrary to this, as the examples of Kandahar und Kunduz reveal, warlordism is very strong in exactly those regions where the state, at least in the perception of elites, is regarded as decisive for power distribution. Thus, warlords often enough perceive the state as a desirable arena of influence. To hold a government office provides certain legitimacy. This is why the egalitarian tribal structures in Paktia, where the state is hardly recognized as a legitimate point of reference, prevent the consolidation of warlordism. It seems that Charles Tilly's (1985) argument - that warlordism is a concomitant phenomenon of state-building processes rather than being diametrically opposed to it - also proves true in the case of Afghanistan.

The role of the international community is difficult to judge. The presence of international actors has led to the disappearance of weapons in public; warlords and militias were forced to keep a low profile. This trend is particularly visible in those Afghan provinces that are being heavily funded by the international 
community (e.g. Kabul, Herat). Moreover, for many warlords a share of the international resources constitutes a vital economic incentive. Often a division of labor within one family can be observed. The best example is the Karzai family: While Hamid Karzai is the Afghan president, his half-brother Ahmed Wali Karzai was the dominant warlord and drug baron in Southern Afghanistan. After his assassination Hamid Karzai appointed Shah Wali Karzai, another half-brother, as his successor. Hamid Karzai's cousin, Hekmat Karzai, runs the "Centre of Conflict and Peace Studies" - an NGO, fully depending on donor funds -, while his older brother, Hashmat Karzai, owns a security company that has millions of dollars in contract with the USmilitary.

However, the international presence does not always tame violence. Apart from the direct military operations of NATO, it was the establishment and equipping of Afghan warlords and their militias by the US-army that caused the temporary emergence of warlordism with Bacha Khan in Paktia and continues to determine the security in Kandahar to this day. Especially since it becomes obvious that NATO intends to withdraw in the near future, it can be observed that the interventionists gave up the idea of building a state-owned monopoly of violence. In parallel to this fracturing of security, a militarization of Afghan society across the country is taking place. Not only do commanders store weapons for future use, but the US army has been equipping "auxiliary forces" with weapons, and the Iranian and Pakistani governments have been equipping insurgents.

\section{Conclusion}

Even though a broad definition of the term 'warlord' can be applied to many actors of violence in Afghanistan, it fails to take into account the variety of local configurations. While the presence of the state and of international actors has a direct influence on the ground, socioeconomic conditions primarily shape the configurations of violence. The concentration of power at the local level in Afghanistan is so strong, that even the core institutions of the state are under control of local interests.

Finally, it has to be stated that the occasional sensational use of the term 'warlord' in the international media between 2001 and 2005 has been replaced by headlines using the term 'Taliban' or 'insurgents' since 2006 in order to make sense of the highly dynamic political structures in Afghanistan. As a result, the debate on warlordism has become more of a sideshow, which is subordinated to the conflict between the insurgents and the state. However, this discourse defining the lines of conflict in Afghanistan expresses more the concerns of the interventionists than it reflects the highly differentiated local realities.

\section{References}

Baldauf, Scott (2004): Warlord Politics Heats Afghan Vote, accessed at: http://www.csmonitor.com/2004/1006/p01s01wosc.html

Gall, Carlotta (2004): Afghan Poppy Growing Reaches Record Level, UN Says, in: New York Times, November 19.

Giustozzi, Antonio (2007): Koran, Kalashnikov and Laptop The Neo-Taliban Insurgency in Afghanistan. London: Hurst

Giustozzi, Antonio (2008): Bureaucratic façade and political realities of disarmament and demobilisation in Afghanistan, in: Conflict, Security \& Development 8 (2), pp. 169-192

Giustozzi, Antonio (2009a): Empires of Mud. Wars and Warlords in Afghanistan. London: Hurst

Giustozzi, Antonio, ed. (2009b): Decoding the New Taliban. Insights from the Afghan Field. London: Hurst

Giustozzi, Antonio/Christoph Reuter (2011): The Insurgents of the Afghan North. Afghanistan Analyst Network. http://aanafghanistan.com/uploads/AAN-2011-Northern-Insurgents. pdf

Glatzer, Bernd (2002): The Pashtun Tribal System, in: Georg Pfeffer and Deepak Kumar Behera (Ed.): Concept of Tribal Society. New Dehli: Concept Publish, pp. 265-282.

Janata, Alfred/Reihanodin Hassas (1975): Ghairatman - Der gute Paschtune - Exkurs über die Grundlagen des Paschtunwali, in: Afghanistan Journal 2 (3), pp. 83-97.

Noelle, Christine (1997): State and Tribe in Nineteenth Century Afghanistan. Richmond: Curzon Press.

Schetter, Conrad (2005): Warlords und Bürgerkriegsökonomie in Afghanistan. In: Claudia Gomm-Ernsting \& Annett Günther (Hg.): Unterwegs in die Zukunft. Afghanistan - drei Jahre nach dem Aufbruch vom Petersberg. Grundlagen und Perspektiven deutsch-afghanischer Sicherheitskooperation. Berlin: Berliner Wissenschafts-Verlag, pp. 102-142.

Schmeidl, Susanne/Masood Karokhail (2009): The Role of Nonstate Actors in 'Community-based Policing': Possibilities and Limitations of the Arbakai (Tribal Police) in Southeastern Afghanistan. Contemporary Security Policy 30 (2), pp. 318342

Tilly, Charles (1985): War-Making and State-Making as Organized Crime, in: Peter Evans et al. (Ed.): Bringing the State Back in. Cambridge: Cambridge University Press, pp. 169-191.

Trives, Sébastien (2006): Afghanistan: réduire l'insurrection: le cas du sud-est, in: Politique étrangère 71 (1), pp. 105-118. 